\title{
FENOMENOLOGI PRAKTIK TAX PLANNING PADA WAJIB PAJAK BADAN
}

\author{
Nurul Farida \\ Unti Ludigdo \\ Gugus Irianto
}

Program Pascasarjana Fakultas Ekonomi dan Bisnis Universitas Brawijaya Jl. MT. Haryono 165 Malang, Telp 08113423508

Abstract

This study aims to reveal the meaning of the tax planning practice undertaken by the taxpayer. The meaning excavations carried out not only on the taxpayer, but also carried on the tax consultant. This is done because the tax consultant besides as a taxpayer also serves more than one taxpayer, so the meaning of tax planning practice undertaken by the taxpayer who obtainable much deeper. Transcendental phenomenology research method used in this study to reveal the related phenomena to the reason for the tax payers do tax planning practice. The results found that there are five reasons tax payers do tax planning practice, tax planning is permitted by the Act, the preferred business goals is to maximize the operating profit after taxes, the lack of fairness in taxation, especially in collecting tax, the existing tax system that makes taxpayer less comfortable, and the dualism obligation make taxpayers more likely to run a religious charity than pay taxes.

Key words: meanings, phenomenology, tax planning, tax payers

Abstrak

Penelitian ini bertujuan untuk mengungkap makna praktik tax planning yang dilakukan oleh wajib pajak. Penggalian makna dilakukan tidak hanya pada wajib pajak saja tetapi juga dilakukan pada konsultan pajak. Hal ini dilakukan karena konsultan pajak selain sebagai wajib pajak juga melayani lebih dari satu wajib 
pajak, sehingga makna praktik tax planning yang dilakukan oleh wajib pajak yang diperoleh lebih mendalam. Metode penelitian fenomenologi transendental digunakan dalam penelitian ini untuk mengungkap fenomena terkait dengan alasan wajib pajak melakukan praktik tax planning. Hasil penelitian menemukan terdapat lima alasan wajib pajak melakukan praktik tax planning, yaitu tax planning diperkenankan oleh Undang-undang, memaksimalkan laba usaha setelah pajak, belum adanya keadilan pajak terutama dalam pemungutan pajak, sistem perpajakan yang ada yang membuat wajib pajak kurang nyaman, dan adanya dualisme kewajiban membuat wajib pajak lebih cenderung menjalankan religious charity daripada membayar pajak.

Kata kunci: makna, fenomenologi, tax planning, wajib pajak

\section{PENDAHULUAN}

Dewasa ini penerimaan dari sektor perpajakan merupakan primadona dan sumber penerimaan utama yang digunakan untuk membiayai pengeluaran pemerintah dan pembangunan dibandingkan penerimaan dari sektor migas dan sektor non pajak. Pada periode 2005-2011, penerimaan dari sektor perpajakan merupakan penerimaan terpenting dalam anggaran pendapatan dan belanja, kurang lebih $80 \%$ dari penerimaan negara bersumber dari pajak. Sedangkan penerimaan yang lain sebesar $20 \%$ bersumber dari migas, non migas, bagian laba BUMN, PNBP lainnya dan pendapatan BLU. Dengan demikian, apabila pengeluaran pemerintah semakin besar dalam rangka pembiayaan negara, tentunya menuntut adanya peningkatan penerimaan negara yang salah satunya berasal dari penerimaan perpajakan sebagai penyumbang terbesar pendapatan negara.

Kondisi target penerimaan pajak yang semakin meningkat menjadi tugas berat bagi Direktorat Jenderal Pajak untuk merealisasi penerimaan tersebut, berbagai upaya dilakukan untuk meningkatkan penerimaan perpajakan. Salah satu upaya yang dilakukan pemerintah dalam meningkatkan penerimaan perpajakan adalah dengan melakukan tax reform, yaitu dengan melakukan reformasi terhadap peraturan perundang-undangan perpajakan sejak tahun 1983 dan terakhir pada tahun 2009 yang lebih dikenal dengan modernisasi pajak. Pada tahun 2008, dalam rangka meningkatkan penerimaan dalam sektor pajak pemerintah menjalankan program sunset policy (UU No. 28 tahun 2007 tentang KUP Pasal 37A). Usaha ekstensifikasi maupun intensifikasi telah dicanangkan oleh Direktorat Jenderal Pajak untuk meningkatkan penerimaan negara dari pajak. Pada tanggal 30 september 2011, secara serentak Direktorat Jenderal Pajak akan melaksanakan kegiatan besar yang dilakukan secara nasional dalam rangka meningkatkan penerimaan perpajakan, kegiatan ini dinamakan dengan sensus pajak nasional (SPN) (Rizal, 2011).

Namun, langkah-langkah yang telah dilakukan oleh DJP dalam rangka mengoptimalisasi penerimaan perpajakan belum menampakkan pencapaian penerimaan 
yang diharapkan. Apabila dilihat dari data DJP tentang realisasi penerimaan perpajakan yang dihimpun dari berbagai sumber selama 5 (lima) tahun terakhir ini, realisasi penerimaan perpajakan yang dikelola DJP terhadap target APBN masih belum menunjukkan hasil yang mengembirakan dari target yang diharapkan, yaitu $100 \%$. Kecuali pada tahun 2008, terjadi surplus realisasi penerimaan pajak yang diakibatkan adanya program sunset policy. Pada tahun 2006, dari target Rp. 333 triliun (di luar $\mathrm{PPh}$ migas) hanya mampu direalisasikan oleh DJP sebesar Rp. 314,5 triliun, sehingga terjadi short fall penerimaan perpajakan Rp. 18,5 triliun. Demikian juga yang terjadi pada tahun 2007, dari target Rp.395 triliun, DJP mengalami short fall Rp.47 triliun (Parwito, 2007). Memasuki tahun 2009, setelah program sunset policy tidak lagi dijalankan, target penerimaan pajak DJP pun kembali tidak dapat direalisasikan. Pada tahun 2009 realisasi penerimaan pajak DJP hanya mencapai Rp.565,77 triliun (termasuk PPh migas) atau sebesar 97,99\% dari target APBN sehingga terjadi short fall 11,6 triliun (Dirjen_Pajak, 2010). Begitu pula yang terjadi pada tahun 2010, penerimaan pajak tahun 2010 tercatat sebesar Rp 649,042 triliun (termasuk PPh migas) atau 98,1\% dari target dalam APBN-P 2010 yaitu sebesar Rp 661, 498 triliun, sehingga DJP mengalami lagi short fall sebesar Rp 12,4 triliun (Budi, 2011).

Fenomena penerimaan pajak yang belum mencapai target tersebut disebabkan oleh banyak faktor, salah satunya adalah adanya kendala dari wajib pajak terutama dalam hal kepatuhan untuk memenuhi kewajiban pajak (tax compliance). Kesadaran individu, pebisnis dan perusahaan untuk membayar pajak sesuai dengan realitas yang ada masih rendah (Subagyo \& Oktavia, 2010). Rendahnya tingkat kepatuhan wajib pajak dalam membayar pajak menyebabkan penerimaan negara akan berkurang dan roda kehidupan bernegara tidak akan bisa berjalan dengan baik karena sumber penerimaan negara terbesar bersumber dari pajak. Bagi perusahaan maupun pebisnis, akan memiliki keuntungan tersendiri dengan membayar pajak sesuai realitasnya, karena kelangsungan bisnis dimasa datang dapat terjamin.

Tujuan pemerintah untuk memaksimalkan penerimaan dari sektor pajak bertentangan dengan tujuan dari Wajib Pajak (WP), dimana WP berusaha untuk mengefisiensikan beban pajaknya sehingga memperoleh keuntungan yang lebih besar dalam rangka untuk mensejahterakan pemilik dan melanjutkan kelangsungan hidup perusahannya. Setiap perusahaan berusaha untuk mencapai tingkat laba yang maksimal, karena itu perusahaan dituntut untuk dapat selalu mengantisipasi setiap kebutuhan dari pada customer, misalnya saja dengan menyediakan produk dengan barang yang berkualitas dan pelayanan yang memuaskan, sehingga diharapkan penjualan/ pelayanan dapat ditingkatkan dan biaya dapat ditekan seminimal mungkin (cost reduction). Dalam upaya menekan biaya tersebut diperlukan adanya suatu perencanaan yang baik terhadap dimensi-dimensi biaya agar dapat dicapai tingkat laba yang optimum.

Pada dasarnya tidak seorangpun suka membayar pajak dan berpotensi untuk bertahan tidak membayar pajak meskipun status Wajib Pajak (WP) sudah melekat, 
sehingga selalu berusaha meminimalkan pembayaran pajak terhutang dengan melakukan perencanaan pajak (tax planning) dan cenderung melakukan tax evasion (Mills, Erickson, \& Maydew, 1998). Perusahaan besar memiliki peluang lebih kecil dibandingkan perusahaan kecil dalam melakukan tax planning (Mills, et al., 1998). Praktik tax planning yang umum dilakukan wajib pajak lebih cenderung pada pajak penghasilan (PPh) dan pajak atas real estate serta memanfaatkan kematian sebagai salah satu bagian dari tax planning (Scroggin, 2005).

Secara teoritis tax planning merupakan bagian dari manajemen pajak. Tax planning merupakan upaya legal yang dilakukan wajib pajak dengan memanfaatkan hal-hal yang tidak diatur atau celah yang ada dalam undang-undang dan peraturan perpajakan (loopholes) (Darmayasa \& Hardika, 2011). Lebih jauh, loopholes perpajakan adalah sebuah keadaan, peraturan, transaksi atau kejadian yang memungkinkan seseorang atau badan usaha mendapatkan peluang penghematan pembayaran pajak atau terhindar dari kewajiban perpajakan tertentu atau terhindar dari pengenaan sanksi administratif perpajakan.

Dari penjelasan di atas dapat dilihat bahwa tax planning (perencanaan pajak) berbeda dengan tax evasion (penggelapan/penyelundupan pajak). Tax evasion adalah upaya wajib pajak dengan penghindaran pajak terutang secara illegal untuk menekan pengeluaran-pengeluaran pajak yang dikelola dalam perusahaan, seperti melanggar undang-undang, double book keeping, pembayaran pajak dengan cek kosong, penerbitan atau menggunakan faktur pajak fiktif serta memotong atau memungut pajak (PPh, PPN) pihak lain tetapi tidak disetorkan dan atau tidak dilaporkan (Lubis, 2009, p. 38). Cara yang ditempuh berisiko tinggi dan berpotensi dikenakan sanksi pelanggaran hukum/tindak pidana fiskal atau kriminal.

Dalam menyusun sebuah tax planning, terdapat dua cara yang dapat dilakukan oleh perencana pajak (tax planner) perusahaan yaitu tax saving dan tax avoidance karena perbuatan seperti itu tidak melanggar undang-undang. Terdapat kemiripan antara tax saving dan tax avoidance, namun secara teoritis pengertiannya berbeda. Tax saving adalah usaha memperkecil jumlah pajak yang tidak termasuk dalam ruang lingkup pemajakan, sedangkan tax avoidance adalah usaha yang sama dengan mengeksploitir celah-celah yang terdapat dalam ketentuan peraturan perundangundangan perpajakan, dimana aparat perpajakan tidak dapat melakukan tindakan apa-apa (Pohan, 2011, p. 15).

Suryanti (2010) menemukan bahwa PT Arta Design melakukan tax planning untuk meminimalkan pembayaran pajak penghasilan dengan memanfaatkan celah undang-undang perpajakan dari segi biaya yang diperkenankan sebagai pengurang Penghasilan Kena Pajak. Selain itu, PT Rajawali Dwi P. juga melakukan tax planning dengan pemilihan metode pembelian dalam pembelian kendaraan dan akhirnya memilih menggunakan leasing dengan hak opsi sebagai alternatif pembelian tujuh unit truk baru agar dapat melakukan tax saving (penghematan pajak) (Chrisdianto \& Andrianto, 2009). Selain itu, rasio total benchmarking merupakan 
salah satu aspek yang harus diperhatikan dalam penyusunan perencanaan pajak (Darmayasa \& Hardika, 2011). Perubahan tarif pajak juga menjadi salah satu faktor wajib pajak melakukan tax planning. Terkait dengan adanya perubahan tarif pajak, penelitian yang dilakukan oleh Scholes, et al. (1992) telah membuktikan bahwa perusahaan di Amerika Serikat melakukan penundaan pengakuan laba kotor pada tahun sebelum diberlakukannya pengurangan tarif pajak. Di Indonesia, Subagyo dan Oktavia (2010) menemukan bahwa perusahaan manufaktur melakukan manajemen laba (tax planning) dalam rangka merespon perubahan tarif pajak Badan di Indonesia. Dengan maraknya praktik tax planning yang dilakukan oleh wajib pajak, pemerintah seharusnya tanggap dan segera mencegah dengan kebijakan pemerintah (Weisbach, 2003).

Dengan mengacu kepada uraian di atas, peneliti memandang praktik tax planning merupakan suatu fenomena yang dapat merugikan negara. Oleh karena itu, pada penelitian ini, peneliti melakukan penelitian dengan pendekatan kualitatif untuk mengeksplorasi alasan wajib pajak melakukan tax planning. Dengan ini maka tujuan penelitian ini adalah untuk memahami alasan wajib pajak dalam melakukan praktik tax planning.

\section{METODE PENELITIAN}

Untuk memahami alasan diimplementasikannya praktik tax planning sebagai sarana dalam menghitung jumlah pajak penghasilan, maka peneliti membawa penelitian ini menggunakan metode penelitian kualitatif. Paradigma yang digunakan dalam penelitian ini adalah paradigma interpretif. Paradigma interpretif lebih menekankan pada makna atau interpretasi seseorang terhadap sebuah simbol. Tujuan penelitian dalam paradigma ini adalah memaknai (to interpret atau to understand, bukan to explain dan to predict) sebagaimana yang terdapat dalam paradigma positivisme (Triyuwono, 2009, p. 217).

Pendekatan yang digunakan adalah fenomenologi. Fenomenologi merupakan pandangan berpikir yang menekankan pada fokus kepada pengalaman-pengalaman subjektif manusia dan interpretasi-interpretasi dunia (Moleong, 2011, p. 15). Pada penelitian ini menggunakan fenomenologi transendental karena tipe ini berorientasi pada penemuan makna dan hakikat dari pengalaman. Hal ini dikarenakan, terdapat perbedaan antara fakta dan esensi dalam fakta, atau dengan kata lain perbedaan antara yang real dan yang tidak (Kuswarno, 2009, p. 40).

\section{Informan dan Pengumpulan Data}

Informan dalam penelitian ini menggunakan 4 konsultan pajak dan 5 wajib pajak. Konsultan pajak yang menjadi narasumber memiliki pengalaman sebagai konsultan rata-rata lebih dari 3 tahun dan salah satu konsultan pajak merupakan mantan pegawai pajak. Adapun wajib pajak yang menjadi informan dalam penelitian 
ini adalah direktur sekaligus owner dari perusahaan. Pengumpulan data dilakukan melalui interiew dengan teknik wawancara tidak terstruktur, peneliti sebagai participant observation dan Pengamatan terhadap interaksi informan (WP, tax professional, dan konsultan) dalam menyikapi tax planning yang akan dijalankan perusahaan

\section{Teknik Analisis}

Pada penelitian kualitatif, proses analisis data dapat dilakukan oleh peneliti pada saat maupun setelah pengumpulan data. Penelitian ini menggunakan tipe fenomenologi transendental maka peneliti menganalisis data dengan mengesampingkan pengalaman peneliti terlebih dahulu untuk mengambil perspektif pertama (fresh perspective) dari sebuah fenomena yang diamati. Metode analisis data dalam penelitian ini dibagi dalam tujuh tahap (Kuswarno, 2009, p. 69) yaitu: (1) Membuat daftar dan pengelompokkan awal data yang diperoleh, (2) Mereduksi dan eliminasi informasi, (3) Mengelompokkan dan memberi tema setiap kelompok invariant constitutes yang tersisa dari proses eliminasi. (4) Identifikasi final terhadap data yang diperoleh melalui proses validasi awal data. (5) Mengkonstruksi deskripsi tekstural masing-masing informan, termasuk pernyataan-pernyataan verbal dari informan, yang berguna bagi penelitian selanjutnya, (6) Membuat deskripsi struktural, yakni penggabungan deskripsi tekstural dengan variasi imajinasi dan (7) Menggabungkan deskripsi tekstural dan struktural untuk menghasilkan makna dan esensi dari permasalahan penelitian. Hasilnya haruslah representasi tema secara keseluruhan.

\section{HASIL PENELITIAN DAN PEMBAHASAN}

Tujuan pemerintah untuk memaksimalkan penerimaan dari sektor pajak bertentangan dengan tujuan dari Wajib Pajak (WP), dimana wajib pajak berusaha untuk mengefisiensikan beban pajaknya sehingga memperoleh keuntungan yang lebih optimal dalam rangka untuk mensejahterakan pemilik dan melanjutkan kelangsungan hidup perusahaan. Setiap perusahaan berusaha untuk mencapai tingkat laba yang maksimal, karena itu perusahaan dituntut untuk dapat selalu mengantisipasi setiap kebutuhan dari pada customer, misalnya saja dengan menyediakan produk dengan barang yang berkualitas dan pelayanan yang memuaskan, sehingga diharapkan penjualan/pelayanan dapat ditingkatkan dan biaya dapat ditekan seminimal mungkin (cost reduction). Dalam upaya menekan biaya tersebut diperlukan adanya suatu perencanaan yang baik terhadap dimensi-dimensi biaya agar dapat dicapai tingkat laba yang optimum.

Terdapat perbedaan kepentingan antara wajib pajak dengan pemerintah dalam perpajakan akan mempengaruhi wajib pajak untuk mengurangi pembayaran pajaknya, atau dengan kata lain wajib pajak enggan membayar pajak sesuai dengan realitas yang ada. Pada dasarnya tidak seorangpun juga suka membayar pajak dan berpotensi untuk bertahan tidak membayar pajak meskipun status wajib pajak sudah 
melekat, sehingga selalu berusaha meminimalkan pembayaran pajak terutang dengan melakukan tax planning dan cenderung melakukan tax evasion (penyeludupan pajak). Sehingga dalam hal ini sangat wajar jika pemerintah mencegah terjadinya kerugian pajak (tax losses) dan mendorong kepatuhan wajib pajak untuk membayar pajak sesuai dengan realita yang ada.

Dalam usaha meminimalkan pembayaran pajak, wajib pajak berusaha menggunakan cara-cara yang legal (tax planning). Namun, wajib pajak juga sering kali menggunakan cara-cara yang illegal (tax evasion). Namun, pada kenyataannya wajib pajak kurang begitu paham dengan yang dinamakan tax planning. Hal ini seperti yang diungkapkan oleh Bapak Heru:

Saya tidak tahu apa yang dinamakan dengan tax planning, yang saya tahu bagaimana caranya supaya saya tidak membayar pajak yang cukup tinggi. Yang penting tidak melanggar Undang-undang dan Laporan pajak saya tertib, bayar tepat waktu dan lapor tepat waktu...

Hal ini sejalan dengan pernyataan Bapak Supianto

Saya ini orang bodo, saya tidak tahu apa yang dinamakan tax planning. Sebagai warga negara saya ya harus bayar pajak tapi ya gitu ojo nemennemen. Sebab banyak sekali teman saya yang tidak membayar pajak padahal usahanya lebih besar dari saya. Tapi kalau semua berpikiran seperti itu mau dapat uang dari mana negara ini. Oleh sebab itu, yaa mari kita membayar pajak dengan seihklas hati kita.

Kebanyakan wajib pajak di Negara kita menggunakan jasa konsultan pajak untuk memenuhi kewajiban perpajakan mereka. Sehingga dalam penyusunan tax planning sebuah perusahaan konsultan pajak juga mempunyai peran yang cukup penting. Namun, wajib pajak tidak boleh percaya begitu saja dengan konsultan pajak, wajib pajak harus memahami bagaimana teknik tax planning yang dilakukan sehingga tidak menimbulkan kerugian dikemudian hari.

Perencanaan pajak (tax planning) merupakan langkah awal dalam manajemen pajak dimana pada tahap ini dilakukan pengumpulan dan penelitian terhadap peraturan perpajakan, dengan maksud dapat diseleksi jenis tindakan penghematan pajak yang akan dilakukan. Tujuan perencanaan pajak adalah merekayasa agar beban pajak (tax burden) serendah mungkin dengan memanfaatkan peraturan yang ada. Tetapi hal ini berbeda dengan tujuan pembuatan Undang-undang maka tax planning disini sama dengan tax avoidance karena secara hakikat ekonomis kedua-duanya berusaha untuk memaksimalkan penghasilan setelah pajak (after tax return), karena pajak merupakan unsur pengurang laba yang tersedia baik untuk dibagikan kepada pemegang saham maupun diinvestasikan kembali (Attahkrim, 2012). 
Surahmat dalam Lubis (2009, p. 15) berpendapat bahwa, "Masalah dalam tax planning bukan terjadi pada saat ini atau dalam waktu dekat, tetapi terjadi dalam lima hingga sepuluh tahun yang akan datang, sehingga sudah menjadi snowball". Bapak Sugiharto menyampaikan:

Menurut saya tax planning itu diibaratkan kita sedang berjalan di atas jurang yang curam apabila sekali salah langkah maka kita akan terperosok ke dalam jurang penggelapan pajak.

Sehingga dalam penyusunan tax planning kita harus berhati-hari agar tidak menimbulkan kerugian yang lebih besar dikemudian hari. Terdapat dua kategori pelaksanaan tax planning yang dilakukan oleh wajib pajak, yang pertama kepatuhan (compliance), yaitu kepatuhan manajemen terhadap semua aturan pajak yang sifatnya sudah rutin dilakukan dan tidak boleh terlambat; dan yang kedua tax planning yang sifatnya tidak rutin dan akan bergantung pada kegiatan perusahaan.

Pajak merupakan salah satu beban/biaya yang harus dikelola oleh manajemen dalam mencapai tujuan organisasi dengan hasil yang maksimal, efisien dan efektif tanpa melanggar ketentuan yang berlaku. Secara umum tujuan tax planning adalah untuk meminimalisasi kewajiban pembayaran pajak (penghematan pajak) baik sekarang maupun akan datang tanpa melanggar ketentuan perpajakan (lawful) agar dicapai laba yang maksimal. Sehingga wajar saja jika wajib pajak berbondongbongdong untuk melakukan tax planning agar mencapai hasil yang diinginkan. Bapak Danu mengungkapkan:

Tax planning menurut saya wajar kita lakukan, dengan melihat kaidah

kaidah, dan payung undang undang perpajakan yang berlaku, dan tidak dilakukan dengan cara illegal.

Wajib pajak melakukan tax planning tentunya memiliki maksud dan tujuan yang jelas. Tidak mungkin wajib pajak melakukan tax planning tanpa didasari alasan-alasan yang mendukung.

\section{Undang-Undang Perpajakan}

Pajak merupakan pungutan yang pelaksanaanya didasarkan pada undangundang perpajakan. Secara benar pajak bukan kontribusi yang sifatnya sukarela dan tanpa ada imbalan balas jasa langsung dari pemerintah. Tetapi, pajak merupakan iuran yang dapat dipaksakan berdasarkan pada undang-undang. Undang-undang merupakan peraturan yang harus dipatuhi oleh semua warga negara. Oleh sebab itu, dalam penyusunan sebuah undang-undang harus disesuaikan dengan kepentingan pembuat kebijakan sehingga dapat tercapai tujuan yang inginkan.

Fenomena yang kita jumpai dalam masyarakat dimanapun ia berada, kalau bisa tidak membayar pajak sama sekali atau jika membayar pajak, bisa dikurangi tanpa harus melanggar Undang-undang (Pohan, 2011, p. 2). Ini hal yang sangat mendasar dari sifat alamiah manusia. Siapapun dia adanya dan apapun pangkat 
atau jabatannya akan selalu berusaha bertindak efisien dalam seluruh kehidupan perseoraangan, maupun dalam siklus kehidupan bisnisnya.

Undang-undang perpajakan (tax law) yang mengatur setiap permasalahan secara sempurna, sehingga dalam pelaksanaannya selalu diikuti oleh ketentuanketentuan lain (Peraturan Pemerintah Keputusan Presiden, Keputusan Menteri Keuangan dan Direktur Jendral Pajak) (Attahkrim, 2012). Sehingga seringkali ditemukan ketidaksesuain antara aturan pelaksanaan dengan Undang-undang itu sendiri. Adanya ketidaksesuaian tersebut yang sering dimanfaatkan wajib pajak untuk melaporkan kewajiban perpajakannya.

Tax planning merupakan upaya legal yang dilakukan wajib pajak dengan memanfaatkan hal-hal yang tidak diatur atau celah yang ada dalam undang-undang dan peraturan perpajakan (loopholes) (Darmayasa \& Hardika, 2011). Seperti yang disampaikan oleh Bapak Sugiharto:

Kalau Ibu menanyakan mengapa saya melakukan tax planning?, ya....

karena tax planning itu diperbolehkan oleh Undang-undang, jadi tax

planning itu legal untuk dilakukan. Tidak ada yang salah dengan tax

planning...

Wajib pajak berasumsi tax planning masih legal dilakukan dan marak dilakukan. Hal ini dikarenakan dalam Undang-undang itu sendiri memberikan peluang bagi wajib pajak.

Masing-masing pihak memang berhak mencari cara yang paling efisien bagi kepentingannya, baik itu kepentingan pihak otoritas pajak maupun kepentingan tax payer. Kata kunci yang utama adalah kepastian hukum (Undang-undang) yang ditunjukan adanya hukum positif yang mengatur yang jelas tegas dan tidak bermakna ganda dan berpotensi menimbulkan sengketa-sengketa pajak. Oleh sebab itu, untuk menghindari hal-hal yang menyimpang dari tujuan pokok pembuatan undang-undang, maka diperlukan kesesuaian antara undang-undang dan aturan pelaksanaannya.

\section{Memaksimalkan Laba dan Mensejahterakan Karyawan}

Pajak merupakan pungutan berdasarkan undang-undang oleh pemerintah. Secara administratif pungutan pajak dapat dikelompokkan menjadi pajak langsung dan pajak tidak langsung (Wordpress.com, 2012). Pajak langsung dikenakan atas masuknya sumber daya yaitu penghasilan, sedangkan pajak tidak langsung dikeluarkan terhadap keluarnya sumber daya seperti untuk konsumsi atau barang dan jasa. Beban pajak langsung umumnya ditanggung oleh orang atau badan yang memperoleh penghasilan, sedangkan beban pajak tidak langsung ditanggung oleh konsumen atau masyarakat.

Bagi perusahaan pajak yang dikenakan terhadap penghasilan dianggap sebagai biaya/beban dalam menjalankan atau melakukan kegiatan usaha. Pajak sebagai biaya akan mempengaruhi besarnya laba yang diterima maupun yang akan 
dikembalikan kepada pemegang saham. Jadi pada dasarnya secara ekonomis pajak merupakan unsur pengurang laba yang tersedia untuk dibagikan atau diinvestasikan kembali oleh perusahaan.

Dalam praktek bisnis umumnya pengusaha mengidentifikasikan pembayaran pajak sebagai beban. Sehingga pengusaha akan berusaha untuk meminimalkan pembayaran pajak tersebut, untuk mengoptimalkan besarnya laba. Hal ini sudah menjadi prinsip ekonomi yang berlaku umum dikalangan pebisnis yaitu dengan biaya sekecil mungkin untuk mencapai untung/laba yang maksimal. Hal ini sejalan dengan pernyataan Bapak Heru:

Tujuan kita dalam mendirikan perusahaan tentunya ingin untung yang banyak, jadi bagaimana caranya biar biaya-biaya yang tidak perlu dikeluarkan, ditunda pengeluarannya atau kalau mungkin dihapus dan tidak usah dikeluarkan. Salah satu contonhnya ya membayar pajak itu....

Dalam meningkatkan efisiensi dan daya saing maka pengusaha wajib menekan biaya seoptimal mungkin. Demikian juga dengan kewajiban membayar pajak, karena merupakan biaya yang menurunkan laba sesudah pajak. Upaya dalam melakukan penghematan pajak secara legal dapat dilakukan melalui perencanaan pajak (tax planning).

\section{Keadilan Pemungutan Pajak}

Kewajiban membayar pajak bagi setiap warga negara sesuai dengan kemampuan dengan aturan yang sangat mendetail, tidak pukul rata. Warga negara yang mempunyai penghasilan besar pasti kewajiban membayar pajaknya besar, begitu pula sebaliknya warga negara yang memiliki penghasilan kecil maka membayar pajaknya juga kecil. Sebagai contoh, PPNBM barang mewah yang pajaknya sampai milyaran, karena memang kemampuannya besar (untuk pembelian misalnya: Lamborghini atau Jaguar), sebaliknya orang pedesaan hanya terhutang Pajak Bumi dan Bangunan membayar cuma Rp. 10.000,- pertahun. Sementara untuk fasilitas umum yang dibiayai dari pajak, secara umum tidak ada pembedaan bagi siapa yang boleh menikmatinya. Disini bisa diambil hikmah bahwa kita belajar saling mengisi atau disebut subsidi silang.

Pemahaman diatas seharusnya menjadi pemahaman setiap wajib pajak sehingga membayar pajak dalam jumlah maksimal dapat tercipta. Namun, fenomena yang sering kita temui dalam masyarakat, wajib pajak dengan pembayar pajak besar tentunya menginginkan sesuatu yang lebih bila dibandingkan pembayar pajak kecil. Sehingga, wajib pajak berusaha menurunkan jumlah pajaknya dengan jumlah seminimal mungkin dengan melakukan tax planning agar dirinya mendapat keadilan dalam ukuran wajib pajak tersebut.

Salah satu alasan wajib pajak melakukan tax planning adalah sistem pemungutan pajak yang tidak merata. Karena masih sering ditemukan orang kaya yang 
tidak membayar pajak. Pegawai pajak (fiskus) lebih senang untuk memaksimalkan yang sudah ada tanpa harus melakukan ekstensifikasi pajak (penambahan jumlah wajib pajak), atau dengan kata lain fiskus lebih senang berburu dalam kebun binatang. Hal ini seperti yang disampaikan oleh Ibu Mahmudah:

Wajib pajak malas untuk membayar pajak, jangan salahkan wajib pajaknya.

Karena orang pajak sendiri lebih senang untuk duduk dibelakang meja dan mengirimi surat wajib pajak yang sudah ada, dari pada turun kelapangan untuk melakukan pencarian wajib pajak yang mana yang seharusnya membayar pajak tinggi dan belum terdaftar. Orang pajak lebih suka "berburu dalam kebun binatang". Orang pajak tidak mau sengsara.

Selain itu, alasan wajib pajak melakukan tax planning adalah tidak adanya kontra prestasi secara langsung bagi pembayar pajak baik pelayanan maupun fasilitas. Hal ini diungkapkan oleh Bapak Lazuardi ketika penulis menanyakan "Mengapa Bapak melakukan tax planning?", dan alasan keadilan menjadi alasan nomor satu yang Beliau ungkapkan.

Karena Negara kita tidak memperdulikan pembayar pajaknya, berapapun yang kita bayarkan yang dapat kita nikmati ya sama saja, tidak ada kekhususan. Atau dengan kata lain tidak ada kontra prestasi langsung yang diterima oleh wajib pajak. Seharusnya Negara ini mencontoh bank-bank yang ada, bank memberikan pelayanan lebih terhadap nasabah prioritas jadi nasabah dengan penabung cukup besar diberikan pelayanan dan kenyamanan yang lebih bila dibandingkan nasabah pada umumnya.

Dengan adanya pemahaman tersebut maka Ditjen Pajak harus berupaya mengubah pemahaman wajib pajak tersebut.

Keengganan wajib pajak dalam membayar pajak dapat diminimalisasi dengan memberlakukan fungsi budgetair dan regulered secara tidak terpecah. Pajak sebagai sumber dana dan alat mengatur tatanan sosial ekonomi. Dari sudut pandang kausalitas, beberapa teori pajak yang mendukung Negara berhak memungut pajak, yaitu teori asuransi, teori kepentingan, teori daya pikul, teori bakti dan teori asas daya beli. Teori asuransi, negara melindungi keselamatan jiwa, harta benda dan hak-hak rakyatnya. Berbasis teori kepentingan, pembagian beban pajak kepada rakyat di dasarkan pada kepentingan masing-masing orang. Teori daya pikul, beban pajak harus sama berat atau sesuai dengan daya pikulnya. Teori bakti, sebagai warga negara yang berbakti rakyat harus menyadari kewajiban membayar pajak. Teori asas daya beli, dasar keadilan terletak pada akibat pemungutan pajak, pajak dipungut berarti menarik daya beli masyarakat dimana mesti didistribusikan kembali untuk kesejahteraan masyarakat (Mardiasmo, 2006, p. 3).

Berdasarkan teori-teori pajak telah dikemukakan, hanya satu teori,yaitu, teori bakti yang murni tanpa kontraprestasi. Empat teori pajak lainnya menyiratkan kontraprestasi. Ini berarti, keengganan wajib pajak membayar pajak dipecahkan dengan benar-benar mengelola kontraprestasi. Seperti berbasis teori asuransi negara 
hanya berhak memungut pajak jika benar-benar melindungi keselamatan jiwa, harta benda dan hak-hak rakyatnya. Bila tidak benar-benar dapat dipahami memperbesar keengganan wajib pajak membayar pajak berdampak wajib pajak melakukan tax planning untuk meminimalkan pembayaran pajak. Wajib pajak akan sadar membayar pajak dalam keadaan masyarakat mengetahui secara jelas pendistribusian pajak dengan benar. Atau dengan kata lain bukan digencarkan pelayanan satu atap maupun kemudahan membayar pajak, pemecah persoalan keengganan membayar pajak sebenar-benarnya tidak lain distribusi yang benar.

\section{Sistem Perpajakan Kurang Nyaman}

Sebelum reformasi perpajakan dilakukan, sistem pemungutan pajak adalah official assesment system. Ketika sistem ini berjalan mutlak, banyak anggota masyarakat yang memberikan reaksi karena bisa jadi besarnya pajak hasil perhitungan fiskus tidak seperti yang diperhitungkan semula, misalnya jauh lebih besar dan sebagainya. Guna membangun sistem yang konstruktif dalam perpajakan nasional, melalui reformasi perpajakan tahun 1983 telah dilakukan perubahan mendasar atas sistem pemungutan pajak, yakni dengan self assesment system. Adanya sistem yang konstruktif ini membawa manfaat bagi wajib pajak. Hal ini seperti yang diungkapkan oleh Bapak Prijono sebagai berikut:

Sistem pembayaran pajak sekarang tidak ribet, kita tinggal menghitung berapa yang akan kita bayarkan. Lalu kita pergi ke Bank untuk membayar pajak dan bank persepsi itu juga ada di kantor pajak. Selanjutnya kita laporkan ke kantor pajak. Jadi sekali jalan kita bisa bayar sekaligus lapor pajak.

Namun, dalam pelaksanaannya self assesment system juga menimbulkan dampak negatif yang dirasakan oleh wajib pajak, pihak fiskus masih kurang percaya dengan laporan yang disampaikan wajib pajak. Seringkali fiskus juga berfikir suudzon terhadap wajib pajak, sehingga membuat wajib pajak kurang nyaman dengan kondisi ini. Hal ini seperti yang disampaikan oleh Ibu Mahmudah:

Sekarang kita kembalikan ke diri kita masing-masing, jika bisa bayar pajak kecil kenapa tidak dilakukan toh bayar pajak besar pun tidak jelas kemana arah tujuannya. Sebagai contoh, kita sudah menghitung, melapor, membayar masih aja kena periksa. Jadi sistem pemungutan pajak self assement di Indonesia sudah tidak sesuai sengan faktanya, karena fiskus tidak percaya kepada hasil wajib pajak yang telah kita sampaikan ke kantor Pajak.

Di sisi lain, dampak negatif penerapan self assesment system dalam hal melakukan pemeriksaan pajak, fiskus bisa tebang pilih tergantung pada subjektifitas petugas pajak. Penerbitan surat ketetapan pajak kurang bayar (SKPKB) mutlak diterbitkan jika terjadi pemeriksaan pajak, agar meningkatkan prestasi pegawai pajak. Hal ini pernaha dialami oleh $\mathrm{Bu}$ Veni: 
Memang nih dirjen pajak, kalau pengusaha yang kecil dikejar-kejar kalau yang besar dibiarin saja pada gak berani. Kalau dilakukan pemeriksaan selalu ada kurang bayar. Selama jadi wajib pajak saya tidak pernah merasakan diperiksa kantor pajak, tidak ada temuan dan saya tidak membayar lagi. Selalu saja ada temuan dan ada kurang bayar. Makanya harus pintar-pintarlah kalau mau usaha maju, jangan mau diperas oleh pajak habis-habisan.

Sehingga pelaksanaan self assesment system juga harus diimbangi dengan sistem modernisasi pegawai pajak dan sistem administrasi pajak yang baik, agar tujuan semua pihak dapat tercapai.

\section{Religious Charity dan Pajak}

Di Indonesia terdapat berbagai macam agama yang dianut oleh penduduknya, antara lain islam, hindu, budha, khatolik, kristen dan konghucu. Masing-masing agama mengisyaratkan agar pemeluknya menunaikan kewajiban beragama di samping kewajiban sebagai warga negara. Salah satu kewajiban beragama yang harus ditunaikan adalah religious charity. Sebagai contoh, religious charity yang dilaksanakan oleh pemeluk agama islam adalah membayar zakat.

Penduduk Negara Indonesia mayoritas muslim, sebagaimana diketahui penduduk muslim di Indonesia berjumlah sekitar $87 \%$ dari total penduduk. Walaupun penduduk muslim $87 \%$ dari penduduk Indonesia, tetapi dalam pemasukan pajak tidak berbanding lurus dengan banyaknya jumlah penduduk muslim yang ada. Hal ini mungkin saja disebabkan penduduk muslim enggan membayar pajak, karena telah ada religious charity dalam agama Islam yang biasa disebut zakat. Di Indonesia, seorang muzakki (wajib zakat) adalah juga wajib pajak. Jika diminta memprioritaskan, tentu saja umat Islam lebih rela membayar zakat dari pada pajak, karena lebih bersifat profan dan didorong oleh motivasi beragama dan kesadaran atas imannya (Hafidhuddin, 2006).

Dalam perhitungan Pajak Penghasilan juga telah mengadopsi sistem nishab dalam zakat, yang dikenal sebagai PTKP atau Penghasilan Tidak Kena Pajak, ada nilai minimalnya baru terhutang pajak. Artinya untuk orang orang yang benar benar mepet untuk kebutuhannya juga masih tetap diperhatikan, sama sekali tidak sama dengan upeti. Sehingga wajib pajak yang mempunyai penghasilan dibawah PTKP tidak mempunyai kewajiban untuk membayar pajak.

Pajak dan religious charity merupakan dua hal yang harus dijalankan dengan baik karena setiap warga negara juga merupakan umat beragama. Namun, warga negara lebih cenderung menjalankan religious charity daripada membayar pajak dengan berbagai alasan yang mereka ungkapkan. Seperti pendapat Bapak Ardi:

Sebagai umat Islam, yang penting kita harus membayar zakat. Kalau kita tidak membayar zakat kita akan disiksa oleh Allah, tetapi kalau kita tidak bayar 
pajak kita akan mendapat surat teguran dan paling jahat saya akan dipenjara. Kalau saya disiksa Allah tentu fisik dan batin saya sakit, karena yang mempunyai fisik saya Allah dan siksa itu pasti akan lama karena saya hidup di akhirat pastinya lama. Tetapi kalau saya dipenjara kan hanya fisik saya saja tetapi saya sudah melaksanakan kewajiban saya sebagai umat Islam dan dipenjara mungkin hanya sebentar saja. Saya lebih takut tidak bayar zakat dari pada tidak bayar pajak.

Tidak hanya penduduk muslim saja, penduduk non muslim juga menyampaikan pemikiran yang sama. Bapak Supianto menyampaikan:

Jika menyumbang gereja bisa menghapus kewajiban pajak saya, saya lebih memilih untuk menyumbang gereja dan membantu orang miskin, dari pada membayar pajak. Jika kita menyumbang secara jelas pemanfatannya dapat kita lihat memang untuk kebaikan masyarakat terutama masyarakat miskin dan anak yatim/piatu. Sedangkan pajak, pemerintah kita saja kayak gini, pungutan di mana-mana, korupsi merajalela. Jadi uang pajak yang kita bayarkan tidak akan dinikmati masyarakat kecil. Hanya pejabat berdasi dan yang duduk dikursi empuk yang menikmati.

Melihat hal tesebut tentunya tugas Dirjen Pajak semakin sulit untuk meningkatkan penerimaan pajak jika setiap warga negara di Indonesia berpedoman seperti itu. Pihak fiskus harus berupaya menggandeng pemuka agama untuk menggugah niat wajib pajak agar membayar pajak sesuai dengan kondisi sebenarnya. Di sisi lain, tidak keseluruhan religious charity bisa dikurangkan dalam penghasilan kena pajak. Dari beberapa alasan tersebut, wajib pajak akan berupaya bagaimana kewajiban perpajakan dijalankan tetapi kewajiban yang utama yaitu religious charity tetap dilaksanakan dengan baik, sehingga wajib pajak berupaya untuk melakukan praktik tax planning dalam membayar pajaknya.

Berdasarkan hasil penelitian, peneliti menemukan beberapa hal yang mempengaruhi perilaku wajib pajak untuk meminimumkan pembayaran pajak, antara lain adanya celah undang-undang (loopholes), adanya kepentingan bisnis, aspek keadilan, sistem perpajakan dan adanya kewajiban membayar zakat. 


\section{Motivasi Wajib Pajak Melakukan \\ Tax Planning}

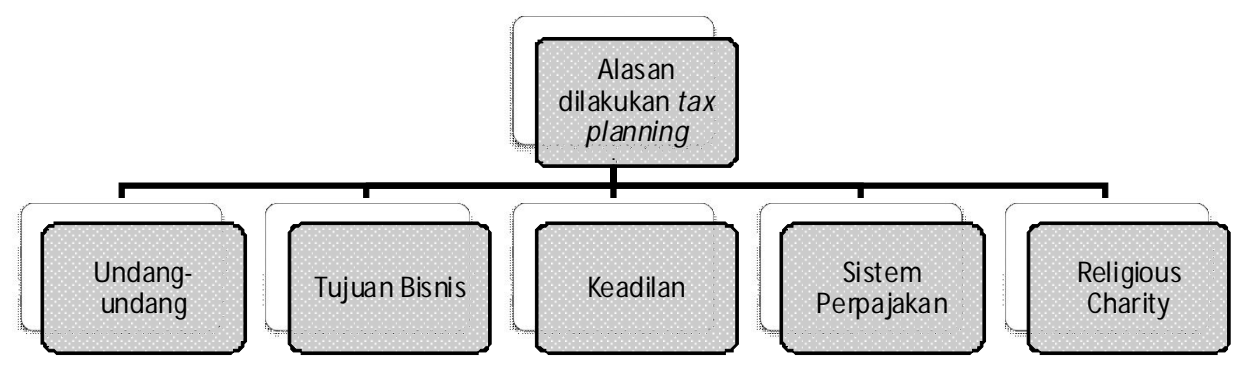

Sumber: hasil penelitian

\section{SIMPULAN}

Atas dasar hasil analisis penelitian yang telah dijelaskan di atas, dapat kita lihat bahwa fenomena praktik tax planning marak dilakukan oleh wajib pajak sebagai saah satu wujud resistensi pajak oleh wajib pajak. Beberapa alasan yang dikemukakan oleh wajib pajak terkait tax planning yang dilakukan yaitu adanya celah dalam undang-undang (loopholes), sistem perpajakan yang ada belum membuat nyaman wajib pajak, wajib pajak merasa belum ada keadilan terutama dalam hal pemungutan pajak, tujuan bisnis yaitu mencapai laba yang maksimal merupakan tujuan utama wajib pajak menjalankan kegiatan usaha, dan adanya religious charity yang lebih diutamakan oleh wajib pajak.

Keterbatasan penelitian ini adalah adanya perbedaan pemaknaan bagi wajib pajak yang secara umum mengartikan bahwa tax planning merupakan sarana untuk pengelakan pajak dan bukan sarana untuk menghemat pajak, menyebabkan hasil penelitian tidak menjelaskan fenomena yang tampak namun lebih menjelaskan pada fenomena terkait apa yang dipahami oleh subyek penelitian. Selain iru, religious charity yang diperoleh penulis hanya berasal dari 3 jenis agama, sehingga tidak diketahui secara mendalam religious charity terkait agama selain subyek penelitian apakah bersifat wajib atau cenderung bersifat sukarela.

Penelitian ini ibarat suatu gambaran dinamika kehidupan yang tidak memiliki kepastian akan pemberhentian selanjutnya. Untuk itu tidak menutup kemungkinan jika hasil penelitian masih perlu digali dalam konteks dan situasi yang lain mengingat situasi ataupun kondisi baik yang terjadi maupun yang dialami oleh seseorang bersifat dinamis. Dari beberapa keterbatasan yang diungkapkan oleh penulis bisa dijadikan sebagai dasar pertimbangan untuk peneliti selanjutnya dalam melakukan penelitian yang senada. Sehingga akan diperoleh makna yang seutuhnya dari praktik tax planning yang ada. 


\section{DAFTAR PUSTAKA}

Attahkrim, M. 2012. Perencanaan Pajak. http://tahkrim.blogspot.com/, diakses 18 Desember 2012.

Budi, C. 2011. Mendongkrak Penerimaan Pajak Perorangan. http://www.investor.co.id, diakses 2 Desember 2012.

Cahyono, A.T., \& Putri, E.E. 2012. Penerapan Zakat sebagai Perencanaan Pajak untuk Efisiensi PPh Badan pada PT. Alwan Zahira Samarinda. Jurnal Eksis, Volume 8 No. 1, 20012181.

Chariri, A. 2009. Landasan Filsafat dan Metode Penelitian Kualitatif. Paper presented at the Workshop Metodologi Penelitian Kuantitatif dan Kualitatif, Laboratorium Pengembangan Akuntansi (LPA), Fakultas Ekonomi Universitas Diponegoro Semarang.

Chrisdianto \& Andrianto. 2009. Penerapan Tax Planning dalam Pengambilan Keputusan terhadap Pilihan Alternatif Pembelian Truk secara Tunai, Kredit Bank dan Leasing dengan Hak Opsi pada PT Rajawali Dwi Putra Indonesia. Jurnal Bisnis Perspektif, Volume 1 No. 1.

Creswell, J.W. 2007. Qualitative Inquiry and Research Design: Choosing Among Five Approaches (2 ed.). California: Sage Publication, Inc.

Darmayanti, T.W. 2004. Pelaksanaan Self Assesment System Menurut Wajib Pajak (Studi Kasus pada Wajib Pajak Badan Salatiga). Jurnal Ekonomi dan Bisnis, Volume X No. 1, 109-128.

Darmayasa, N., \& Hardika, N.S. 2011. Perencanaan Pajak dari Aspek Rasio Total Benchmarking, Kebijakan Akuntansi dan Administrasi sebagai Strategi Penghematan Pajak. Jurnal Bisnis dan Kewirausahaan, Vol. 7 (Nopember 2011).

Dirjen Pajak. 2010. Siaran Pers: Penerimaan Pajak 1 Januari 2009 s/d 31 Desember 2009 dan Kinerja Lainnya. www.pajak.go.id, diakses 2 Desember 2012.

Hafidhuddin, D. 2006. Zakat untuk kesejahteraan bersama. www.budpar.go.id, diakses 7 Nopember 2012.

Kuswarno, E. 2009. Metodologi Penelitian Komunikasi Fenomenologi, Konsepsi, Pedoman dan Contoh Penelitiannya. Bandung: Widya Padjajaran.

Lubis, I. 2009. Memudahkan Urusan Pajak: Bagi Perorangan, Suami-Istri, Usaha dan Yayasan. Jakarta: Kompas Gramedia.

Mangonting, Y. 1999. Tax Planning: Sebuah Pengantar Sebagai Alternatif Meminimalkan Pajak. Jurnal Akuntansi dan Keuangan, Vol. 1, No. 1 .Universitas Kristen Petra, 43-53.

Mardiasmo. 2006. Perpajakan. Edisi revisi. Yogyakarta: Andi Offset.

Mills, L., Erickson, Merle, M., \& Maydew, Edward, L. 1998. Investments in tax planning. The Journal of the American Taxation Association, Volume 20 No. 1 (ABI/INFORM Research).

Moleong, L.J. 2011. Metodologi Penelitian Kualitatif. Bandung: PT Remaja Rosdakarya. Muhadjir, N. 2000. Metodologi Penelitian Kualitatif. Yogyakarta: Rake Sarasin.

Parwito. 2007. Sampai kapan data pajak bisa dipegang?. http://www.ortax.org, diakses 30 Juli 2012. 
Pohan, C.A. 2011. Optimizing Corporate Tax Management: Kajian Perpajakan dan Tax Planning-nya Terkini. Jakarta: Bumi Aksara.

Rizal. 2011. Sensus Pajak Nasional. http://hitungpajak.wordpress.com, diakses 15 Februari 2012.

Scroggin, J.J. 2005. Income Tax Planning Now That Estate Taxes Are Less Significant. Estate Planning ABI/INFORM Research, 32 No. 6.

Subagyo \& Oktavia. 2010. Manajemen Laba sebagai Respon Atas Perubahan Tarif Pajak Penghasilan Badan di Indonesia. Proceeding Simposium Nasional Akuntansi XIII Purwokerto.

Suryanti. 2010. Perencanaan Pajak Untuk Meminimalkan Pembayaran Pajak pada PT. Arta Design. http://www.gunadarma.ac.id, diakses 3 Agustus 2012.

Triyuwono, I. 2009. Perspektif, Metodologi dan Teori Akuntansi Syariah. Jakarta: Rajawali Pers.

Undang-undang No. 16 Tahun 2009 tentang Ketentuan Umum dan Tata Cara Perpajakan. Undang-undang No. 28 Tahun 2007 tentang Ketentuan Umum dan Tata Cara Perpajakan. Undang-undang No. 36 Tahun 2008 tentang Pajak Penghasilan.

Undang-undang No. 38 Tahun 1999 tentang Pengelolaan Zakat.

Weisbach, David. 2003. Corporate Tax Avoidance. Proceeding of the $96^{\text {th }}$ Annual Conference of Taxation, Chicago. 